\title{
UPAYA MENDORONG PARTISIPASI REMAJA DALAM PEMELIHARAAN KEBERSIHAN LINGKUNGAN SUMBER AIR PADA KOMUNITAS PEMULUNG AL BAHAR DEPOK
}

\author{
Elis Anisah Fitriah \\ Fakultas Psikologi UIN Sunan Gunung Djati Bandung, Jl. A.H Nasution No. 105 Bandung \\ email: nengelis_af@yahoo.com
}

\begin{abstract}
Abstrak
Penelitian tindakan ini bertujuan untuk meningkatkan kepercayaan pada komunitas Al-Bahar terhadap sumber air sehingga mengurangi ketergantungan anggota komunitas pada supply air bersih dari luar wilayah mereka. Program ini sudah dilaksanakan dengan menggunakan tehnik partisipatif dan pemberdayaan selama 2 bulan dengan melibatkan 15 orang dewasa yang berpartisipasi aktif menelusuri masalah dan memelihara kebersihan lingkungan sekitar sumber air. Hasil evaluasi program intervensi ini menunjukkan indikasi yang signifikan adanya perubahan kesadaran pada anggota komunitas untuk bertanggung jawab sebagai pengguna sumber air, menjaga kebersihan lingkungan sekitar sumber air, dan ikut mencari ide pemecahan masalah lingkungan.
\end{abstract}

Kata kunci : Penelitian tindakan, komunitas, partisipasi, pemberdayaan

\section{Abstract}

This action research aimed to increase trust of the members of Al Bahar community towards the well water so it could reduce the community's dependences toward clean water supplies from outside. This program has been executed by using participation techniques and empowerment for approximately 2 (two) months with the active involvement of 15 (fifteen) adolescents by increasing their active participation in investigating the problem as well as looking after the environmental sanitation surrounding the wells. The program evaluation of this intervention has showed some significant indications for changes among the members namely awareness of their responsibilities as the user of the wells, reveal their willingness willingness to take care of the environmental sanitation in the area; coming up with ideas to solve some contextual environmental problems.

Keywords: Action research, community, participation, empowerment.

\section{PENDAHULUAN}

Air merupakan sumber kehidupan sekaligus menjadi kebutuhan yang paling mendasar bagi manusia dalam keberlangsungan hidupnya. Dalam UU Nomor 7 tahun 2004 tentang Sumber Daya Air pasal 5 disebutkan bahwa Negara menjamin hak setiap orang untuk mendapatkan air bagi kebutuhan pokok minimal sehari-hari guna memenuhi kehidupan yang sehat, bersih dan produktif. Dalam beberapa dekade terakhir, air bersih kemudian mengalami pergeseran menjadi fungsi ekonomis yakni menjadi komoditi yang diperjualbelikan contohnya air 
mineral maupun air PDAM yang disalurkan ke rumah-rumah penduduk.

Namun saat ini air bersih telah menjadi barang langka yang semakin lama semakin sulit diperoleh secara bebas bahkan merupakan barang mahal yang harus dibeli oleh masyarakat. Perhatian dunia Internasional terhadap ketersediaan air dan hak untuk mengakses air bersih selain dikampanyekan melalui Hari Air sedunia setiap tanggal 22 Maret juga pencanangan 2005-2015 sebagai International Decade for Action-'Water for Life'. Dalam Rencana Strategis Pemerintah RI untuk mencapai Millenium Development Goals, merencanakan target meningkatnya proporsi penduduk yang dapat mengakses air minum yang aman dan berkelanjutan serta fasilitas sanitasi dasar pada 2015 sebagai indikator dari pencapaian tujuan yang ke tujuh yakni memastikan kelestarian hidup. UNICEF dalam pencanangan tahun sanitasi Internasional-2008, menyebutkan bahwa hampir 55 juta rakyat Indonesia tidak memiliki akses terhadap air bersih (Kompas, 28 Maret 2008). Hal ini cukup ironis, karena Indonesia dikenal sebagai negara kepulauan yang sekitar 69 persen wilayahnya adalah daerah perairan, ternyata belum mampu mengoptimalkan potensi airnya agar dapat menjadi air bersih sehingga bisa digunakan untuk memenuhi hajat hidup warga negaranya.

Kelangkaan air bersih tidak hanya bersumber dari kelangkaan fisik, melainkan juga akibat penguasaan air oleh swasta melalui privatisasi, ketidaksetaraan kekuasaan untuk mengontrol ketersediaan air karena kesenjangan ekonomi dan kemiskinan serta isu-isu lingkungan khususnya pemanasan global. Hal lain yang cukup signifikan adalah faktor ketidakpedulian masyarakat untuk menjadikan air sebagai sumberdaya yang diperbarui secara konsisten. Berbagai kegiatan manusia juga seringkali membahayakan keseimbangan dan keberlanjutan ketersediaan air antara lain melalui perilaku mencemari seperti membuang sampah atau limbah ke sumber air permukaan (sungai, situ, laut, waduk), mengeksploitasi air tanah untuk kepentingannya sendiri melalui pengeboran sumur tanpa batas dan pemanfaatan lahan hijau resapan air untuk bangunan.

Untuk dapat mengatasi persoalan kelangkaan air (berkurangnya kuantitas air bersih), rendahnya kualitas air untuk dikonsumsi dan meminimalisir pengeluaran secara ekonomis masyarakat dalam membeli air bersih maka perlu peran serta dari berbagai pihak untuk menjaga ketersediaan air yang bersih dan aman. Khususnya untuk masyarakat dengan kondisi sosial ekonomi menengah ke bawah perlu kiranya diberikan dorongan untuk dapat secara mandiri memenuhi penyediaan air bersih. Selain itu juga perlu upaya-upaya untuk mengurangi dampak negatif dari perilaku-perilaku yang mencemari kualitas air yang ada melalui penyadaran yang kongkrit bagi masyarakat, khususnya generasi muda tentang betapa pentingnya air bagi kehidupan. Persoalan inilah yang akan diangkat dalam program intervensi oleh kelompok kesehatan Intervensi Sosial 2006 di komunitas Al Bahar sebagai kelompok sasaran.

Komunitas Al Bahar terletak di tepi Kali Cipayung di tepi jalan Proklamasi Kelurahan Abadi Jaya RT 09/RW 02 dengan jumlah rumah tangga sebanyak 80 rumah. Wilayah ini dihuni oleh para pendatang yang sebagian besar mata pencahariannya adalah pemulung (50\%), pedagang $(22 \%)$, dan pekerjaan lainnya seperti kuli bangunan, kuli cuci, supir juga tukang becak. Dengan penghasilan sekitar Rp. 500.000 hingga Rp 700.000 setiap bulan dengan rata-rata pengeluaran yang jumlahnya sama, serta kondisi rumah yang mereka huni rata-rata berukuran $6-12 \mathrm{~m} 2$ tanpa fentilasi, berlantai tanah atau hanya sekedar adukan semen, berdinding triplek dan atap seng maka bisa dikategorikan sebagai masyarakat miskin. Status rumah 
yang mereka huni adalah sewa kepada pemilik setiap bulan dengan harga mulai dari Rp. 60.000 hingga Rp.200.000. Ironisnya, pemilik kontrakan tidak menyediakan fasilitas apa pun sebagai sarana sanitasi dasar dan air bersih yang dibutuhkan para penyewa.

Pada tahun 2000 warga secara bergotong royong melakukan penggalian sumur pertama untuk memenuhi kebutuhan atas air bersih yang kemudian disusul dengan sumur kedua pada tahun 2003. Pada periode itu, warga menggunakan air dari sumur tersebut untuk seluruh kebutuhan sehari-hari yakni air minum, mandi, mencuci pakaian, dan peralatan rumah tangga termasuk bahan masakan, berwudhu, dan untuk memasak. Sejalan dengan meningkatnya jumlah penyewa, jumlah keseluruhan sumur yang dimiliki komunitas ini adalah tujuh sumur dan hanya lima yang masih berfungsi sebagai sumber air bersama, dengan kuantitas yang cukup melimpah.

Sayangnya, melimpahnya air di Al Bahar tidak diimbangi dengan kualitas air. Pada musim kemarau, beberapa sumur akan mengalami perubahan warna, bau, dan kedalaman, sebaliknya pada saat hujan sumur-sumur tersebut akan kembali bening, tidak berbau dan permukaannya hampir mendekati bibir sumur. Meningkatnya jumlah warga yang menetap di Al Bahar menjadi persoalan lain yang mengakibatkan sumur tercemar karena tingkat kedisiplinan dalam menggunakan sumur semakin sulit dikontrol. Kebiasaan mandi dan mencuci di dekat bibir sumur membuat air sisa sabun jatuh ke sumur yang tidak bertutup tersebut. Banyaknya sampah di sekitar sumur membuat saluran air yang tidak lancar dan tergenang membuat kondisi sekitar sumur semakin kumuh.

Kondisi-kondisi

tersebut mengakibatkan rendahnya kepercayaan warga untuk menggunakan air sumur sebagai air bersih untuk memenuhi kebutuhan air minum air dan memasak.
Sebagian besar warga memenuhi kebutuhan air bersih untuk konsumsi dengan cara membeli dari penjual keliling ataupun berlangganan ke depot isi ulang. Warga rata-rata membeli air isi ulang sebanyak 20 (dua puluh) liter seharga Rp. 3.000 hingga Rp. 3.500 untuk mencukupi rata-rata 3-5 (tiga hingga lima) hari kebutuhan air minum anggota keluarganya sedangkan air jerigen 20 (dua puluh) liter yang dibeli dari penjual keliling dengan harga Rp.1.500 - Rp. 2.000 untuk kebutuhan memasak selama satu hingga dua hari. Rata-rata pengeluaran rumah tangga untuk air minum dan memasak selama sebulan berkisar Rp. 50.000 hingga Rp. 70.000-an.

Selama ini memang belum ada aturan bersama mengenai pemeliharaan sumur dan perawatan sarana pendukung yang ada. Kebersihan sumur hanya mengandalkan warga yang sadar tanpa ada tuntutan untuk berpartisipasi dalam perawatan sumur. Rendahnya rasa memiliki warga terhadap sumur sebagai fasilitas bersama juga dipengaruhi pandangan warga terhadap ketidakpedulian pemilik dan pengurus kontrakan dalam memenuhi sarana sumur dan kakus sebagai kebutuhan utama penyewa. Akibatnya sumur dan kakus yang mereka bangun sendiri hanya dibuat sekedarnya dan tidak ada gerakan untuk memperbaiki maupun merawatnya.

Permasalahan yang ingin diangkat dalam intervensi ini adalah meningkatkan kesadaran dan gerakan nyata para remaja Al Bahar untuk ikut berpartisipasi dalam menjaga kebersihan di sekitar sumursumur yang ada di Al Bahar. Dengan demikian, lebih jauh lagi diharapkan dapat mendorong perilaku pemeliharaan dari seluruh warga pengguna sumur sehingga mampu mengembalikan kepercayaan masyarakat terhadap kualitas air sumur dan dapat memanfaatkannya secara optimal. Pada akhirnya, warga tidak harus tergantung kepada supplier air dari luar serta mengurangi biaya yang cukup besar 
dalam memenuhi kebutuhan air untuk masak dan minum.

\section{TINJAUAN TEORI}

Untuk memberi landasan pikir yang sesuai dan arahan dalam pelaksanaan program/tindakan yang diharapkan, tinjauan literatur yang digunakan antara lain: Perkembangan remaja, Social Learning theory, Experiential Learning theory, Partisipasi dan Pemberdayaan (teknik intervensi).

Kata "remaja" berasal dari bahasa latin yaitu adolescere yang berarti to grow atau to grow maturity (Golinko, 1984 dalam Rice, 1990). Masa remaja merupakan salah satu periode perkembangan yang dialami oleh setiap individu, sebagai masa transisi dari masa kanak-kanak menuju masa dewasa. Hurlock (1999) pada masa remaja ini ada beberapa perubahan yang bersifat universal, yaitu meningkatnya emosi, perubahan fisik, perubahan terhadap minat dan peran, perubahan pola perilaku, nilai-nilai, dan sikap ambivalen terhadap setiap perubahan. Menurut Erikson (dalam Santrock, 1998) remaja harus dapat mengorganisasikan dan menunjukkan kemampuan, kebutuhan, minat dan keinginan sehingga dapat diekspresikan dalam lingkungan sosial, khususnya menuju peran baru dalam masyarakat.

Dari sudut pandang ecological systems (Bronfenbenner, 1979), penting untuk mempertimbangkan pemahaman hubungan antara individu dan berbagai sistem lingkungan di sekitarnya misalnya keluarga, kelompok teman sebaya, lokalitas, sekolah dan komunitas. Pandangan ini menekankan pentingnya hubungan antar sistem dalam lingkungan tersebut. Remaja dalam lingkungan interpersonalnya sangat dipengaruhi oleh teman sebaya, orang tua, tetangga, guru dan orang lain disekitar dirinya yang memiliki interaksi cukup dekat dengan dirinya. Khususnya teman sebaya, faktor ini sangat memegang peranan penting dalam kehidupan dan perkembangan mereka. Remaja cenderung mengidentifikasi dirinya dengan kelompok sebayanya agar sesuai dan tidak diasingkan. Dengan demikian dari segi emosional teman sebaya bisa berdampak positif (sebagai support group) tapi juga dari sumber tekanan (pressure).

Bila kelompok remaja sebaya dikondisikan sebagai social support group yang menyediakan simpati, bimbingan, pengetahuan, tempat untuk berkreasi, dan sumber afeksi, maka kelompok sebaya seperti ini akan memberikan setting yang positif dalam mengembangkan kemandirian dan keyakinan pada dirinya sendiri. Walaupun remaja telah mencapai tahap perkembangan kognitif yang cukup untuk menentukan tindakannya sendiri, namun penentuan diri remaja dalam berperilaku banyak dipengaruhi oleh tekanan sosial khususnya dari kelompok teman sebaya (Conger, 1991).

Dalam masa remaja terdapat masa psychososial moratorium dimana para remaja mencoba menemukan komitmen hidupnya. Komitmen inilah yang mempengaruhi kemampuannya mengatasi krisis identitas, yang bila berlangsung dengan baik maka remaja tersebut akan membangun nilai berupa identifikasi sejumlah nilai, ideologi, kreativitas, dan lain sebagainya. Nilai-nilai kehidupan kemudian diinternalisasi sebagai bagian dari nilai dinilainya termasuk dalam tindakan ini adalah nilai-nilai pro lingkungan dan kesehatan. Pada periode ini, remaja membutuhkan kesempatan untuk melakukan eksperimen dengan peran-peran sosial yang berbeda seiring dengan perjuangan mereka membentuk jati diri melalui keterlibatan dengan rekanrekan sebaya mereka.

Pendekatan dan proses partisipatoris menjadi penting baik bagi peneliti maupun bagi remaja itu sendiri untuk mendapatkan pengalaman yang sangat berharga tentang bagaimana berkerja dengan mereka, memahami perbedaan perspektif dengan 
orang dewasa sekaligus melihat potensi remaja dalam menghayati lingkungan disekitarnya. Partisipatoris dalam sebuah proses penelitian maupun aksi tidak sekedar partisipasi simbolik melainkan menggabungkan kebutuhan dan pandangan penting remaja dalam proses pembuatan kebijakan maupun pembangunan keluarga, komunitas maupun negara (Mansour Fakih \& Robert Chambers, 2002).

Untuk memberikan kerangka teori yang berguna dalam memahami dan menjelaskan dampak dari lingkungan sosial terhadap perilaku kesehatan remaja, peneliti menggunakan teori Social Learning theory. Teori ini dikembangkan oleh Bandura (1986) yang menjelaskan perilaku sebagai model triadik, dinamis dan timbal balik antara lingkungan sosial, personal (kognitif) dan faktor behavioral yang saling berinteraksi. Ada tiga prinsip dasar dari teori ini yaitu pertama, perilaku dipengaruhi dan bergantung pada konteks dan setting yang dihayatinya. Kedua, faktor sosial ekonomi memiliki peran yang penting dalam membentuk perilaku namun pengaruhnya dimediasi oleh kognitif personalnya. Ketiga, perilaku tidak hanya dipengaruhi oleh kedua faktor tersebut melainkan juga mempengaruhi faktorfaktor tersebut. Sehingga adanya efek perubahan timbal balik yang satu sama lain saling mempengaruhi.

Dalam membuat perilaku baru yang cukup kompleks, perlu penyederhanaan setiap tugas dan memberikan kesempatan untuk mempraktikannya satu per satu secara berulang yang akhirnya akan mendukung terbangunnya self-efficacy untuk menyelesaikan setiap tugas yang ada. Self efficacy adalah derajat kepercayaan seseorang untuk menampilkan perilaku/kegiatan tertentu termasuk didalamnya keyakinan untuk mampu mengatasi berbagai hambatan yang ditemuinya. Melalui pendekatan tersebut, terjadi pula pemahaman mengenai perilaku tersebut (knowledge of the behavior) dan bagaimana melakukannya (skill).
Dalam penelitian tindakan ini, diharapkan dapat dilihat dinamika interaksi antara tiga determinan perilaku yaitu personal (pengetahuan, kepercayaan dan intensi), behavioral (keterampilan, selfefficacy, praktik) dan lingkungan (konteks, situasi, dukungan sosial dari teman, orang tua dan warga lainnya). Melalui dinamika triadik yang digambarkan dalam teori ini maka diharapkan akan mempengaruhi pola timbal balik setiap faktor penentu untuk menampilkan perilaku pemeliharaan lingkungan sumur Al Bahar.

Belajar dari pengalaman sering kali menjadi cara yang tepat untuk merubah perilaku dan penguasaan keterampilan baru. Pengalaman baik yang dialami oleh diri sendiri maupun orang lain memberikan efek pembelajaran yang sangat berharga bagi seseorang. Experiential learning menekankan suatu aksi pembelajaran yang diperoleh dari pengalaman pribadi dan kemudian secara berkelanjutan dimodifikasi untuk meningkatkan efektivitasnya (Johnson \& Johnson, 2000). Proses experiential learning pertama kali dikenalkan oleh Kurt Lewin (1935) yang menekankan bahwa penemuan konsep dan prinsip-prinsip yang berharga oleh seseorang dilakukan melalui pengamatan pengalaman dirinya maupun orang lain. Proses penemuan melalui pengalaman sangat mementingkan partisipasi aktif dalam kelompok dimana seseorang berada agar dapat mempelajari keterampilan, pengetahuan, dan sikap yang baru mengenai kelompok melalui interaksi dan refleksi pengalaman mereka satu sama lain. Pengalaman tersebut kemudian diperbaiki dan dilakukan kembali sehingga keterampilan baru tersebut dikuasai.

Dalam penelitian tindakan ini, kelompok remaja diajak untuk merumuskan permasalahan rendahnya kualitas air sumur Al Bahar menurut pengetahuan dan pengalaman mereka. Kemudian mereka diajak melakukan berbagai simulasi untuk mencari penyelesaian masalah secara berkelompok. 
Selama proses terjadi pertukaran informasi, umpan balik, perdebatan dalam pengambilan keputusan, munculnya pimpinan-pimpinan situasional dan mengevaluasi tindakan yang sudah dilakukan. Dari seluruh proses yang dialami para remaja melalui pengalaman dan dinamika kelompok mereka, diharapkan akan merubah perilaku mereka menjadi pro lingkungan yang menetap sehingga akan menjadikan mereka sebagai agen-agen perubahan yang berkontribusi pada peningkatan kualitas air di sumursumur melalui sistem pemeliharaan.

Secara umum, teknik intervensi dilakukan untuk melalukan perubahan sosial yang bertujuan meningkatkan kesejahteraan manusia pada semua level baik personal hingga organisasional, dari mikro hingga level makro. Untuk melakukan sebuah perubahan sosial, partisipasi dan pemberdayaan merupakan dua sisi mata uang yang tidak terpisahkan karena memiliki hubungan yang erat. Suatu masyarakat akan berdaya bilamana seluruh individu yang ada di dalamnya berpartisipasi. Melalui setiap proses partisipasi maka proses pemberdayaan di tingkat individual sekaligus situasi kemasyarakatan juga sedang terjadi.

Partisipasi merupakan sebuah proses di mana masyarakat dalam sebuah komunitas atau warga sebuah Negara berperan aktif dalam setiap proses pengambilan keputusan dalam lembaga, program, lingkungan yang dapat memberikan dampak dalam kehidupan mereka (K.Heller et. al., dalam Dalton, 2001). Partisipasi dapat ditinjau sebagai sebuah alat atau teknik yang menekankan pada dinamika partisipasi yang terjadi, sedangkan bila dipandang sebagai suatu akhir atau hasil partisipasi merupakan sebuah nilai atau kualitas yang ditetapkan dari suatu masyarakat.

Sebagai sebuah teknik, setiap proses yang terjadi atau bagaimana dinamika untuk terjadinya proses tersebut merupakan hal terpenting. Partisipasi akan terjadi bilamana telah muncul perasaan dan kesadaran diri sebagai bagian dari komunitas (sense of community) pada setiap individu. Selain itu, individu perlu memiliki rasa percaya diri terhadap kemampuan mereka untuk menentukan kehidupan mereka dengan memanfaatkan sumber daya yang mereka miliki. Faktor lain yang berhubungan dengan partisipasi masyarakat yaitu dorongan (provocation) dari lingkungan luar termasuk yang bersifat ancaman terhadap komunitas (Dalton, Elias, Wandersman, 2001).

Kieffer (1984) memberikan skema tentang proses partisipasi masyarakat melalui pemberdayaan individu dan penguatan lingkungan, sebagai berikut:

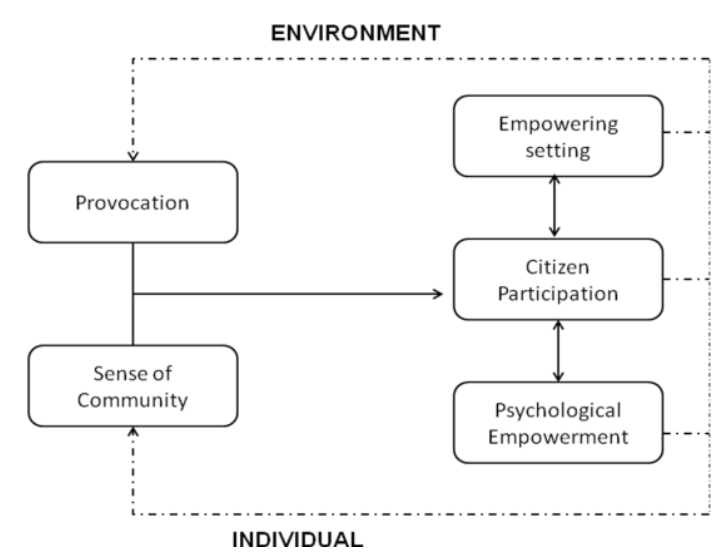

Gambar 1. Model Citizen Participation

Dalam bagan tersebut, baik provokasi maupun sense of community akan mengarahkan kepada partisipasi. Dalam partisipasi terjadi proses timbal balik terhadap kondisi pendukungnya yaitu pemberdayaan psikologis maupun penguatan setting. Agar dapat berpartisipasi secara optimal, seseorang harus memiliki kompetensi yang memadai dimana kondisi tersebut dicapai melalui pemberdayaan psikologis (pengetahuan, skill, keterampilan sosial: komunikasi, leadership, dan lain-lain). Sebaliknya proses partisipasi juga akan berdampak dalam membangun kapasitas dari orang 
yang ada dalam komunitasnya untuk lebih berdaya termasuk juga seting lingkungan.

$$
\text { David Wilcox }
$$

mengemukakan lima tangga partisipasi dan level partisipasi dengan mengadopsi pendekatan "tangga partisipasi" dari Sherry Arnstein (1969). Kelima level tindakan untuk partisipasi meliputi:

a. Information yakni memberikan informasi kepada komunitas mengenai apa yang direncanakan.

b. Consultation. Dalam periode ini, komunitas saling menawarkan sejumlah pilihan dan mendengarkan umpan balik.

c. Deciding together. Keputusan untuk melakukan perubahan dilakukan secara bertahap dengan berbagi tanggung jawab.

d. Acting together. Tahapan implementasi kegiatan yang diputuskan kemudian dilakukan bersama melalui kemitraan.

e. Supporting independent community interests. Pada tingkatan ini, yang dilakukan adalah membantu orang lain melakukan apa yang mereka inginkan lebih lanjut dengan melalui nasihat, dukungan dana, komitmen dan lain-lain.

Remaja dalam intervensi ini ditempatkan sebagai salah satu stakeholder sekaligus agen perubahan. Hal ini menekankan keberadaan remaja sebagai bagian dari komunitas Al Bahar, juga remaja memiliki kekuatan mempengaruhi, baik kepada orang tuanya, teman sebaya, maupun kelompok anak-anak. Kebersamaan dan interaksi mereka dalam lingkungannya cukup menjadi sumber dalam membangun kesadaran bermasyarakat berdasarkan pengetahuan yang telah mereka miliki tentang Al Bahar dan adanya motivasi untuk memperbaiki lingkungan dimana mereka tumbuh dan berkembang agar lebih baik.

Keterlibatan remaja dalam program ini sejak perencanaan hingga evaluasi diharapkan memiliki dampak positif dan berkelanjutan karena:

1. Dengan berkonsultasi dengan kelompok remaja dan komunitas, kita akan mampu membangun kerangka program berdasarkan sudut pandang mereka terhadap realitas yang ditemui;

2. Refleksi terus menerus atas proses pelaksanaan program akan memberi kesempatan belajar dari partisipan sehingga peneliti lebih sensitif dan responsif terhadap berbagai kebutuhan dan minat mereka;

3. Remaja dapat memilih dan turut andil dalam pengambilan keputusan dengan memilih aktivitas mana yang cocok dan mereka minati;

4. Remaja memiliki kontrol dalam pelaksanaan kegiatan dan menggagas isu-isu yang menarik perhatian mereka.

Secara umum, mereka memiliki kemampuan namun perlu diasah lebih lanjut agar bisa melakukan partisipasi. Oleh karena itulah kemudian kegiatan akan lebih banyak difokuskan pada pemberdayaan psikologis dan penguatan social support sangat membantu dalam proses berikutnya yaitu kegiatan dan perilaku terhadap kebersihan lingkungan sesuai keinginan mereka dan sejauh mana mereka bisa mengambil peran dalam memelihara lingkungan di sekitar sumursumur yang ada.

\section{METODE INTERVENSI}

Dari berbagai temuan, baik dalam baseline maupun dalam pertemuan konsultasi dengan warga, peneliti lebih memfokuskan program menjaga kebersihan di sekitar sumur dengan memilih remaja sebagai kelompok sasaran sekaligus agen perubahan. Namun demikian, sebagai sebuah intervensi yang berbasis komunitas, kegiatan ini berjalan bersamaan dengan intervensi terhadap keseluruhan komunitas yang dilakukan secara bersama dengan peneliti yang lain.

Secara khusus, program ini ditujukan untuk mendorong partisipasi remaja $\mathrm{Al}$ Bahar dalam pemeliharaan kebersihan lingkungan sekitar sumursumur Al Bahar melalui penguatan kemampuan individual dan dinamika 
kelompok remaja sebaya. Kelompok remaja usia 12-17 tahun dipilih oleh peneliti sebagai kelompok target dengan pertimbangan sebagai berikut:

a. Pada baseline ditemukan bahwa remaja merupakan pengguna sumur aktif karena beberapa pekerjaan rumah tangga terkait dengan penggunaan air dilakukan oleh remaja, antara lain mencuci pakaian, mencuci alat rumah tangga, mandi, memandikan adik/keponakannya, memasak, mengambil air untuk persediaan di rumah dan lain-lain.

b. Remaja khususnya remaja putri menyatakan kebutuhan dan harapan terhadap sumur dan fasilitas pendukungnya sebagai tempat yang lebih "aman" (terjaga privacy pada saat beraktivitas di sumur/tempat mandi tanpa harus merasa diperhatikan oleh warga lain khususnya pada saat mereka mandi) karena sumur-sumur yang ada sangat terbuka.

c. Dalam baseline, remaja menunjukkan telah memiliki pengetahuan mengenai air dan sadar mengenai pentingnya air bersih bagi kehidupan. Mereka juga mampu mengidentifikasi beberapa solusi untuk memperbaiki kondisi lingkungan mereka. Pengetahuan, kebutuhan, dan harapan ini perlu dipertahankan agar konsisten dan mendorong terpenuhinya perkembangan moral khususnya penanaman nilai kehidupan yang pro lingkungan dan kemandirian.

d. Mayoritas remaja (baik yang bersekolah ataupun tidak) juga memulung dengan paruh waktu, sekitar tiga jam sehari. Mereka memiliki waktu luang yang cukup luang dan mengharapkan ada kegiatan yang bermanfaat untuk mengisi waktu tersebut.

e. Dari sudut pandang ecological system remaja memiliki kemampuan untuk mempengaruhi berbagai lingkungan maupun individu lain disekitar mereka misalnya adik-adiknya, rekan sebaya, tetangga, dan orang tua mereka. Potensi ini perlu dikembangkan untuk mendorong pemberdayaan masyarakat melalui pemberdayaan individual dengan memanfaatkan dinamika kelompok remaja secara suportif dan konstruktif.

Tahapan yang dilakukan selama program intervensi ini selain menggunakan pendekatan experiential learning dengan menempatkan remaja sebagai pusat perhatian maka beberapa strategi yang sesuai dengan karakteristik belajar remaja itu sendiri. Project cycle dari skema rancangan intervensi meliputi beberapa tahap yang sesuai dengan prinsip-prinsip perubahan sosial diuraikan sebagai berikut :

1. Persiapan : Dilakukan untuk mengenali para remaja, mengidentifikasi kesediaan untuk berkomitmen bekerja sama dan menjelaskan tujuan dari kegiatan. Persiapan ini memerlukan waktu yang cukup lama untuk membangun rasa kepercayaan terhadap peneliti serta memperkuat rasa memiliki terhadap program yang akan dilakukan. Dalam tahapan ini para remaja merefleksikan pengalaman dan penghayatan perilaku mereka dalam menggunakan sumur, serta mengumpulkan ide-ide untuk memperbaiki kondisi lingkungan sumur dan kualitas air sumur Al Bahar.

2. Pelaksanaan: Para remaja dikondisikan dalam kelompok, melakukan interaksi, membangun rasa saling percaya dan membagi tugas yang akan dilakukan sesuai minat dan kemampuan. Dinamika kelompok ini kemudian dibangun menjadi bentuk yang lebih formal dengan mengajak para remaja untuk lebih terorganisir melalui pembentukan kelompok. Kelompok inilah yang kemudian merancang setiap tahapan yang bisa mereka lakukan dalam mencapai tujuan yang diharapkan, mengevaluasinya dan menentukan langkah berikutnya. Proses belajar mengamati, mengalami, menghayati dan membangun pengetahuan serta 
kemampuan sosial baru menjadi fokus dalam tahapan pelaksanaan ini.

3. Monitoring: Dilakukan untuk memantau sejauh mana perkembangan dari kegiatan, dinamika yang terjadi dalam kelompok maupun indikator fisik lingkungan yang bisa diamati sebagai hasil dari pelaksanaan. Proses ini juga dilakukan secara partisipatif dengan mengapresiasi indikasi-indikasi temuan dan langkah koreksi yang diambil oleh kelompok remaja tersebut agar proses pelaksanaan tetap mengarah pada pencapaian tujuan bersama.

4. Evaluasi: Dilakukan kepada target group untuk mengetahui perubahan pengetahuan mengenai air, kondisi lingkungan sumur selama program, dan relasi mereka dalam kelompoknya. Evaluasi ini juga dilakukan dengan pendekatan partisipatif dimana kelompok remaja memiliki kesempatan yang sama untuk menilai seberapa besar perubahan mereka bisa lihat dan rasakan. Evaluasi ini lebih bersifat kualitatif dibandingkan kuantitatif dengan berdasarkan indikator yang sudah ditentukan dalam matriks Logical Framework Analysis.

\section{Hasil Intervensi dan Pembahasan}

Linney dan Wandersman (1991) menawarkan empat langkah dasar dalam melakukan evaluasi terhadap program yang berdasarkan logic model, meliputi evaluasi terhadap tujuan dan hasil yang diinginkan, proses, capaian dan dampak dari kegiatan. Bila dibandingkan dengan kondisi sebelum kegiatan intervensi ini terjadi, maka bisa dikatakan bahwa warga mulai membangun kepercayaan mereka terhadap sumber air yang ada di lingkungannya seiring dengan pembangunan sumur khusus yang bisa mereka konsumsi khususnya untuk memasak. Pembangunan sumur khusus untuk konsumsi oleh warga, menjadi perwujudan kemampuan warga untuk memecahkan persoalan rendahnya kualitas air yang kemudian membuat mereka tergantung kepada supplier air dari luar. Keterlibatan seluruh lapisan masyarakat di lingkungan Al Bahar menjadi sebuah bukti bahwa persoalan air merupakan persoalan bersama dan dengan saling bekerja sama, apa yang menjadi tujuan bersama yakni tersedianya air bersih yang berkualitas bisa dicapai.

Ditinjau dari sisi proses, evaluasi mempertanyakan apakah desain yang digunakan sesuai untuk mencapai tujuan yang diharapkan. Hal ini terkait dengan apakah semua langkah yang dilakukan sesuai rencana/kronologi dari setiap kejadian. Bila ditinjau dari keseluruhan kegiatan yang direncanakan dan tingkat partisipasi dari remaja sebagai target group maka ada satu kegiatan belum tercapai karena waktu yang belum memungkinkan. Dari tingkat kehadiran, rata-rata remaja yang mengikuti kegiatan sekitar $75 \%$ dari keseluruhan remaja yang ditargetkan. Jumlah ini meningkat bilamana dihitung dengan bertambahnya partisipasi remaja dari luar wilayah target (bukan pengguna sumur, tetapi teman sebaya-bermain mereka).

Dari sisi evaluasi ketercapaian hasil maka dapat dilihat dari tabel di bawah ini:

Tabel 1. Evaluasi Hasil

\begin{tabular}{|c|c|c|}
\hline $\begin{array}{c}\text { KONDISI } \\
\text { AWAL }\end{array}$ & METODE & KONDISI AKHIR \\
\hline $\begin{array}{l}\text { Tidak ada } \\
\text { wadah dan } \\
\text { kegiatan } \\
\text { remaja }\end{array}$ & $\begin{array}{l}\text { Dinamika } \\
\text { Kelompok }\end{array}$ & $\begin{array}{l}\text { Remaja memiliki kelompok } \\
\text { yakni Kelompok Remaja } \\
\text { Pecinta Kebersihan } \\
\text { Lingkungan dan Sumur } \\
\text { (PKLS) dengan struktur } \\
\text { organisasinya. } \\
\text { Mulai tumbuhnya rasa } \\
\text { kebersamaan dan empati } \\
\text { terhadap temannya yang } \\
\text { berasal dari antar blok } \\
\text { Kegiatan remaja secara } \\
\text { regular setiap hari Minggu } \\
\text { untuk membersihkan } \\
\text { lingkungan sumur dan } \\
\text { kegiatan lainnya yang } \\
\text { dirancang bersama. }\end{array}$ \\
\hline
\end{tabular}




\begin{tabular}{|c|c|c|}
\hline $\begin{array}{l}\text { Rendahnya } \\
\text { kepedulian } \\
\text { dan } \\
\text { keterlibatan } \\
\text { remaja dalam } \\
\text { memelihara } \\
\text { kebersihan } \\
\text { lingkungan } \\
\text { dan sumur }\end{array}$ & 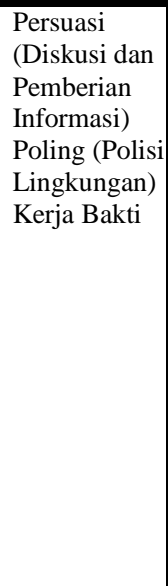 & $\begin{array}{l}\text { Mulai munculnya kesadaran } \\
\text { mengenai pentingnya } \\
\text { menjaga kebersihan } \\
\text { lingkungan sumur agar } \\
\text { menjaga kualitas air } \\
\text { Munculnya keberanian para } \\
\text { remaja untuk memberikan } \\
\text { teguran terhadap warga } \\
\text { (khususnya anak kecil) yang } \\
\text { tidak menjaga kebersihan } \\
\text { sumur } \\
\text { Adanya gerakan kerja bakti } \\
\text { membersihkan lingkungan } \\
\text { sumur setiap Minggu. } \\
\text { Remaja mulai mencari } \\
\text { alternatif upaya untuk } \\
\text { pengadaan dan perbaikan } \\
\text { fasilitas sumur }\end{array}$ \\
\hline $\begin{array}{l}\text { Tidak adanya } \\
\text { upaya } \\
\text { perbaikan } \\
\text { sumur dan } \\
\text { fasilitas } \\
\text { pendukung } \\
\text { sumur }\end{array}$ & $\begin{array}{l}\text { Penggalangan } \\
\text { dana melalui } \\
\text { proposal } \\
\text { Pengadaan } \\
\text { barang } \\
\text { Kerja bakti }\end{array}$ & $\begin{array}{l}\text { Remaja mulai berani } \\
\text { mengemukakan pendapat } \\
\text { dan harapannya kepada } \\
\text { orang tua } \\
\text { Remaja memiliki inisiatif } \\
\text { dan melakukan pengadaan } \\
\text { dan perbaikan fasilitas sumur } \\
\text { (tempat sampah, gentong, } \\
\text { ember timba bersama, } \\
\text { gayung, sikat) di } 2 \text { sumur } \\
\text { yang paling banyak } \\
\text { penggunanya. }\end{array}$ \\
\hline
\end{tabular}

Meskipun program intervensi ini masih pada tahapan awal munculnya kompetensi partisipasi dari remaja yang menjadi target kegiatan, namun beberapa indikasi yang mengarah kepada dampak perubahan dari keberdayaan remaja $\mathrm{Al}$ Bahar. Dampak perubahan dari proses partisipasi dicirikan melalui :

1. Remaja lebih terlibat dalam kegiatan dan munculnya rasa memiliki terhadap proses maupun hasil yang terjadi.

2. Remaja lebih kreatif dalam mengusulkan solusi yang sesuai dengan realitas yang mereka amati dan hayati,

3. Remaja lebih "komit" terhadap keberadaan kelompok dengan kemauan yang kuat untuk mempertahankan kelompok PKLS sebagai wadah kegiatan kreativitas remaja, tidak semata-mata pada pemeliharaan lingkungan sumur.

Metode yang digunakan dalam evaluasi ini, selain dengan observasi, rekam proses dan wawancara, juga dilakukan participatory evaluation, dimana remaja diberikan kesempatan untuk menilai ketercapaian harapan dan kebutuhan mereka dari program yang mereka ikuti. Berikut adalah penilaian mereka terhadap efektivitas program :

\section{Tabel 2. Hasil Evaluasi Remaja terhadap Program}

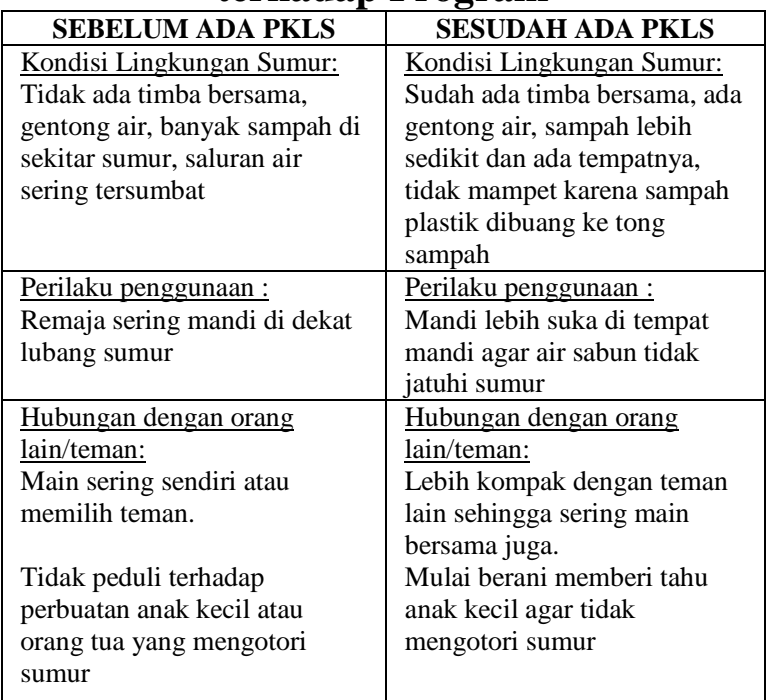

\section{SIMPULAN DAN SARAN}

Ada beberapa simpulan yang dapat ditarik dari kegiatan ini antara lain:

1. Melibatkan dan mendengarkan suara remaja dalam setiap proses penelitian dan intervensi memberikan peluang kepada peneliti, komunitas dan remaja itu sendiri mengenai besarnya kemampuan remaja berkontribusi dalam perubahan dan pembangunan komunitas.

2. Membuat desain kegiatan untuk remaja menggunakan

pendekatan "participatory learning and action" cukup berhasil menarik ide, motivasi dan intensi dari remaja untuk lebih terlibat dalam setiap tahapan dari merencanakan hingga mengevaluasi kegiatan.

3. Untuk merubah perilaku terkait dengan penggunaan sumur, tidak terlepas dari perubahan fisik sumur dan fasilitas pendukung yang memadai. Pengetahuan warga dan remaja pada khususnya mengenai perilaku yang mencemari sumur tidak sejalan dengan perilaku yang dimunculkan karena warga selalu 
menjadikan fasilitas fisik sebagai salah satu hambatan.

4. Meningkatkan kesadaran untuk berpartisipasi perlu didorong oleh halhal provokatif yang bersifat konstruktif sehingga remaja merasa kegiatankegiatan yang dilakukan sebagai bagian dari kebutuhan mereka.

5. Dukungan dari support group khususnya orang tua menjadi faktor kunci untuk membuat para remaja tetap konsisten dalam mengikuti kegiatan dan memotivasi mereka dalam mempertahankan kegiatan kerja bakti membersihkan lingkungan khususnya sumur.

Untuk dapat memperbaiki kegiatan ini dimasa mendatang sebagai tindak lanjut kegiatan, maka peneliti menyarankan:

1. Perlu kiranya ada upaya lanjutan untuk meningkatkan kesadaran dan keterampilan hidup bersih dan sehat tidak hanya pada level personal remaja melainkan sebagai keseluruhan komunitas. Untuk remaja khususnya, dengan memasuki masa pubertas dan rendahnya kontrol orang tua terhadap perilaku sosial mereka, isu-isu seperti kesehatan reproduksi dan personal hygiene perlu menjadi perhatian.

2. Waktu yang hanya 2 bulan untuk berinteraksi bagi remaja dengan peneliti masih dirasakan kurang optimal. Semangat mereka untuk terlibat dalam kegiatan masih cukup tinggi dan adanya harapan memperluas jenis kegiatan yang meningkatkan kemampuan mereka dalam menguasai keterampilan hidup untuk bekal di masa mendatang.

3. Mengingat pemeliharaan kebersihan sumur merupakan tanggung jawab seluruh penggunanya, perlu kiranya upaya intervensi lanjutan bagi warga $\mathrm{Al}$ Bahar untuk membuat aturan bersama, melakukan pengelolaan fasilitas umum dan air bersih secara swadana dan swadaya.

\section{DAFTAR PUSTAKA}

Dalton, J., Elias, M. J., \& Wanderman, A (2001). Community Psychology: Linking Individuals and Communities. Stamford: Wadsworth.

Fakih, M., \& Chambers, R. (2002). Anakanak Membangun Kesadaran Kritis. Yogyakarta: REaD Book.

Johnson, D.W., \& Johnson, F.P. (2006). Joining Together: Group Theory and Group Skills. Boston: Allyn and Bacon.

Santrock, J.W. (1998). Adolescence. New York: McGraw Hill

Sarwono, S. (2002). Psikologi Sosial: Individu dan Teori-teori Psikologi Sosial. Jakarta: Balai Pustaka.

Smet, Jo.,\& Van Wijk, C. (2002). Small Communities Water Supplies: Technology, People and Partnership. Netherlands: IRC International Water and Sanitation Center.

Wollman, N., Foderraro, M., Lobenstine, M., \& Stose, S. (1998). Principles for Promoting Social Change.The Society for the Psychological Study of Social Issues.

Wilcox, D. (1994). The Guide to Effective Participation. http:// www.partnership.org.uk.

Zaltman, Gerald., Kotler, Philip., \& Kaufman, Ira (1972). Creating Social Change. New York: Holt, Rinehart and Winston, Inc. 